\title{
Another family with acute vitamin D intoxication: another cause of familial hypercalcaemia
}

\author{
R.B. Thomson and J.K. Johnson \\ Dumfries \& Galloway Royal Infirmary, Bankend Road, Dumfries DG1 4AP, Scotland, UK.
}

\begin{abstract}
Summary: Acute vitamin D intoxication from an unknown source occurred in a family consisting of a grandmother, mother, father and four children aged 14, 11, 8 and $1 \frac{1}{2}$ years old. The clinical presentation and response to treatment (which included a diphosphonate preparation and cholestyramine) are described.
\end{abstract}

\section{Introduction}

Cases of intoxication with massive therapeutic doses of vitamin D have become less common since the danger was recognized (Chaplin et al., 1951). Poisoning with preparations not intended for human consumption is unusual. Acute severe vitamin D intoxication in a family was previously described in this Journal (Down et al., 1979). This was due to the use, for cooking, of a highly concentrated vitamin D preparation in nut oil which was intended to have been an additive in the manufacture of animal food. Such multiple acute poisoning with this vitamin must be extremely rare but the family here described had similar features which demonstrated the clinical presentation and difficulty in treating this condition.

\section{Clinical history}

A family of parents and 4 children aged $14,11,8$ and $1 \frac{1}{2}$ years were well until the weekend before Christmas, 1981, when the three older children, all boys, were noted to be unusually thirsty. Over the next few days, father and the three boys developed nausea and vomiting, the boys being more severely affected than the father. The mother felt nauseated but did not vomit. The youngest child, a 17 month old girl, had no symptoms. One set of grandparents arrived to stay over the Christmas holiday, and left one week later, the grandmother feeling unwell.

The three boys were the most severely affected, particularly $\mathrm{S}$ aged 11 years. He was admitted to

Correspondence: J.K. Johnson, M.B., M.Sc., M.C.B., F.R.C.Path

Accepted: 27 May 1986 hospital 2 weeks after the onset of symptoms with a diagnosis of 'food poisoning'. His two brothers were admitted 48 hours later. All three boys had anorexia, vomiting, constipation and polydipsia.

On admission to hospital S (aged 11 years) and D (aged 14 years) were clinically dehydrated, yet significantly hypertensive ( $\mathrm{S}$ had a blood pressure of 170 / $110 \mathrm{mmHg}$ and $\mathrm{D}$ of $150 / 95 \mathrm{mmHg}$ ). Initially both $\mathrm{S}$ and $\mathrm{D}$ were conscious and orientated, but lethargic with slow slurred speech and tremulous limb movements. D had a dry cough, pleuritic chest pain and toothache. S had one episode at home of twitching of the limbs. During the 3 days after admission to hospital his conscious level deteriorated and he progressed into a stupor.

It had been ascertained initially that $S$ had an extremely high serum calcium level of $3.95 \mathrm{mmol} /$ litre (normal 2.12-2.62) and subsequently calcium levels were measured from all family members. D had an admission serum calcium level of $3.81 \mathrm{mmol} /$ litre.

A, aged 8 years, was less severely affected clinically, as he was adequately hydrated, remained mentally alert and was normotensive. It is interesting to note therefore that his was the highest initial serum calcium level of the family at $4.08 \mathrm{mmol} /$ litre.

All three boys, but no other members of the family, had marked conjunctival suffusion.

$\mathrm{K}$, aged 17 months, had been irritable but otherwise asymptomatic. Clinical examination was normal. Her serum calcium level was $3.64 \mathrm{mmol} /$ litre.

The mother and father reported relatively mild symptoms at the onset of the boys' illness, but were well 2 weeks later when the family presented to hospital. Both were mildly hypertensive, but showed no other clinical abnormality. Their serum calcium

C The Fellowship of Postgraduate Medicine, 1986 
levels were 3.78 and $3.38 \mathrm{mmol} /$ litre respectively.

The grandmother was complaining of a sore jaw by the timi of leaving this family's home after a week's stay. The symptoms cleared after a few days. Her general practitioner collected a blood sample 2 days after the admission to hospital of the three boys and the serum calcium level was $2.72 \mathrm{mmol} /$ litre. Grandfather had no symptoms and was not tested. No further investigation or follow-up was arranged for grandparents, and discussion about results from family members subsequently in this report do not include the grandparents.

\section{Laboratory investigations and diagnosis}

The acute onset of the illness, and the findings of severe hypercalcaemia in all family members, with symptoms recognized to be associated with hypercalcaemia, strongly suggested a diagnosis of vitamin D intoxication, although there was no history of vitamin D medication.

Hyperparathyroidism was excluded, as parathyroid hormone levels were undetectable in serum from all family members.

Vitamin $\mathrm{D}$ intoxication was later confirmed by finding extremely high levels of 25 hydroxyvitamin D in serum from each of them ranging from 832 to $1287 \mathrm{nmol} /$ litre (normal 0-50) (Table I).

\section{Progress}

The parents were initially treated only with a high oral fluid intake. $\mathrm{K}$ was treated similarly, but also received prednisolone until serum calcium became normal. Forced diuresis was initially carried out for the three boys followed by high oral fluid intake, low calcium diet and prednisolone until serum calcium was within the normal range. $S$ and $A$ received phosphate initially, but not $\mathrm{D}$ because of his very high serum urea and creatinine. In addition, all three boys were treated with the diphosphonate preparation disodium etidronate ('Didronel') in a dose of $20 \mathrm{mg} / \mathrm{kg}$ before breakfast each day for 24 days, in an attempt to reduce bone resorption.

The three brothers improved symptomatically and were well enough to go home when serum calcium levels were normal. $\mathbf{S}$ and $\mathbf{D}$ had initial evidence of renal dysfunction with raised urea and creatinine after rehydration, returning to normal within 2 weeks, although they remained hypertensive.

Slit lamp examination of the boys' eyes revealed conjunctival injection with crystalline deposits, and an interpalpebral band shaped keratopathy which cleared completely in one month.

The levels in blood from mother, father and the four children had all returned to within the reference range in 24 days after admission. The urine calcium level in the three brothers had also returned to normal within 24 days.

The three brothers did not return to full vigour for 3 months, and did not regain their usual weight until much later. During these months $S$ and $D$ were anorexic and lethargic, and remained hypertensive, while D's dry cough and pleuritic chest pain persisted.

Although serum calcium values returned to normal within 24 days, serum $25-\mathrm{OH}$ vitamin D levels remained high on follow-up for one year (Figure 1) Because of the possibility of long term effects, pare ticularly on the kidney, such as described previously in this Journal (Down et al., 1979) the mother and the three boys were given cholestyramine in doses appropriate for weight $(12,10,6$ and $4 \mathrm{~g}$ /day respectively) in an attempt to accelerate the excretion of vitamin $D$. The father was not treated.

Five months after Christmas, the parents' $25-\mathrm{OH}$ cholecalciferol value had fallen to a level acceptable for residents in a sunny climate (about $200 \mathrm{mmol} / \mathrm{litre}$ ) but 12 months after the event, the levels were still raised above the reference range of $0-50 \mathrm{mmol} /$ litre for this country (father 212, mother 141).

Table I Initial levels of relevant serum constituents

\begin{tabular}{|c|c|c|c|c|c|}
\hline Patient & $\begin{array}{l}\text { Calcium } \\
(\mathrm{mmol} / \mathrm{l})\end{array}$ & $\begin{array}{l}\text { Phosphate } \\
(\mathrm{mmol} / \mathrm{l})\end{array}$ & $\begin{array}{c}25-O H \text {-vitamin } D \\
(\text { nmol } / l)\end{array}$ & $\begin{array}{c}\text { Urea } \\
(\mathrm{mmol} / \mathrm{l})\end{array}$ & $\begin{array}{c}\text { Creatinine } \\
(\mu \mathrm{mol} / \mathrm{l})\end{array}$ \\
\hline $\mathbf{S}$ & 3.95 & 1.5 & 864 & 25.2 & - \\
\hline D & 3.81 & 1.6 & 956 & 16.2 & 281 \\
\hline $\mathbf{A}$ & 4.08 & 1.0 & 1121 & 7.0 & 90 \\
\hline $\mathbf{K}$ & 3.64 & 2.0 & 832 & 7.6 & 52 \\
\hline Mother & 3.78 & 1.2 & 969 & 7.6 & 107 \\
\hline Father & 3.38 & 1.0 & 1287 & 11.7 & 230 \\
\hline Grandmother & 2.72 & - & - & - & - \\
\hline $\begin{array}{l}\text { Reference } \\
\text { range }\end{array}$ & $2.12-2.62$ & $0.8-1.4$ & $0-50$ & $3.5-7.5$ & $62-124$ \\
\hline
\end{tabular}




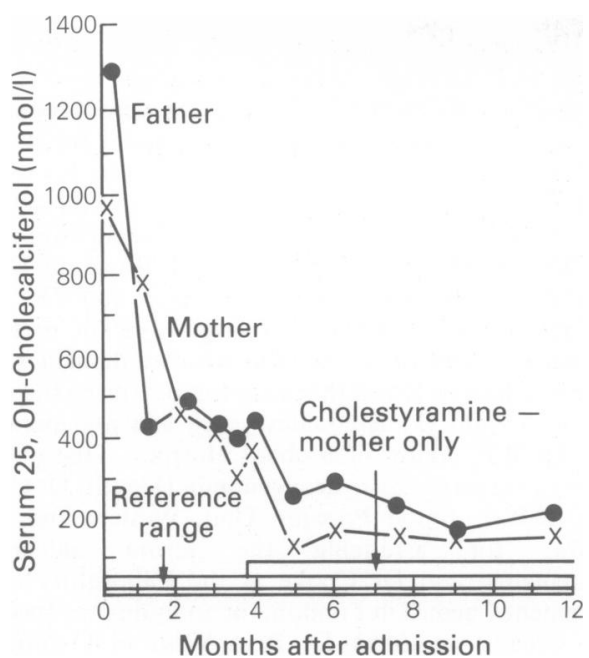

Figure 1 Levels of serum 25-hydroxycholecalciferol in the mother $(\mathrm{x}-\mathrm{x})$ and father $(\mathrm{O}-\mathrm{O})$.

\section{Discussion}

It is presumed that the family must have ingested either a potent vitamin D-containing medication or foodstuff contaminated with vitamin $D$. Despite a search of the house by the Public Health Authority no source was found.

As the vitamin is fat soluble, cooking oils and fats were considered. Two years previously, the family had been given nut oil in an unlabelled tin, which they had used for the first time that Christmas to cook chips. The oil from the chip-pan had been discarded but a sample of oil, said to be from the unlabelled tin, was analysed by a Government chemist, and did not contain significant amounts of vitamin $D$.

The two most likely explanations for hypertension were a direct action of either hypercalcaemia or vitamin D in the blood vessels, or a secondary effect caused by release of renin from damaged kidneys. Plasma aldosterone was undetectable in blood taken from $A$ and $D$ when they were hypertensive. This makes it extremely unlikely that there had been a release of renin and substantiates the findings that hypertension can be caused directly by hypercalcaemia (Marone et al., 1981). It also suggests that the hypertension in patients with hyperparathyroidism is due to the hypercalcaemia rather than the level of parathyroid hormone (Sangal \& Beevers, 1983).

The use of diphosphonates and polyphosphonates in medicine was reviewed by Russell (1975). The drugs reduce bone resorption by preventing the dissolution of hydroxyapatite crystals, impair osteoclastic activity and prevent ectopic calcification.

On theoretical grounds, we considered that they should be potentially useful in this family in the acute phase, to help reduce serum calcium levels, without the risk of ectopic calcification which is present with other forms of therapy such as oral phosphate. The drug, ethane-1-hydroxy-1, 1-diphosphonate (EDHP, disodium etidronate, 'Didronel') was used. This has previously been used to treat ectopic calcification in children by Uttley et al. (1975).

The three boys had 24 days of diphosphonate treatment beginning one week after admission. A longer course was considered to be inadvisable because of possible impairment of bone mineralization. As other family members were by then asymptomatic, they were not treated.

There was no significant evidence of a decrease in urine excretion of calcium during this treatment, and radiological examination of bone was normal. It is not possible to say whether this treatment had any effect in preventing ectopic calcification.

In addition to its other properties, it has been claimed that cholestyramine has avidity for $25-\mathrm{OH}$ vitamin $\mathrm{D}$ in vitro, and also that it binds water-soluble metabolites and conjugates of vitamin D (Queener \& Bell, 1976; Rosenberg et al., 1979). With the parents' informed consent, it was therefore decided to treat the mother with cholestyramine and compare the rate of all of her levels of serum $25-\mathrm{OH}$ vitamin D over the next year, with those of her untreated husband who would act as a control subject. The levels in both parents were similar, soon after the commencement of therapy at $471 \mathrm{nmol} /$ litre in mother and $485 \mathrm{nmol} /$ litre in father. The first 10 weeks of treatment resulted in a more rapid fall in the mother's levels than those of the father, to 221 and $412 \mathrm{nmol} /$ litre respectively. The long term effect, however, does not seem to have been significant at this dosage.

The value of cholestyramine treatment of vitamin $D$ intoxication is therefore questionable, but acting on the initial fall in the mother's level, the three boys were also treated with the resin for 6 months.

There was no significant rise in the serum 1,25dihydroxycholecalciferol levels in blood from the parents, but it was not totally suppressed. This confirms that the second hydroxylation in the kidney is independent of the substrate (25-OH vitamin D) concentration and is in keeping with the view (Frazer, 1980) that 1-hydroxylase activity is activated by serum parathyroid hormone, as this hormone was undetectable in blood from all members of the family on admission, and from the parents for 12 months afterwards.

The serum calcitonin level, however, was never raised in specimens from the parents collected for 12 months after the poisoning; in fact, those from the mother were low throughout this period. It would have been expected that the initial high serum calcium levels would have resulted in a release of the hormone and $a$ rise in the serum concentration. 
This family and the parents described in the previous case in this Journal (Down et al., 1979) illustrate the difficulty of achieving a rapid, safe fall in the hypercalcaemia due to severe vitamin D intoxication.

In this case, because of concern about the clinical condition of the three boys in the acute phase and because of potential long-term effects such as ectopic calcification, therapy was tried with diphosphonates and cholestyramine. These drugs are well established in different clinical circumstances, but although there are sound theoretical reasons to justify their use in vitamin $\mathbf{D}$ intoxication, there are no previous reports of their use for this purpose. In this family, we have been unable to show that either drug made any significant difference to the clinical or biochemical course of treated family members.

\section{References}

CHAPLIN, A., CLARKE, L.D. \& ROPES, M.W. (1951). Vitamin D-Intoxication. American Journal of Medical Science, 221, 369.

DOWN, P.F., POLAK, A. \& REGAN, R.J. (1979). A family with massive acute vitamin $\mathrm{D}$ intoxication. Postgraduate Medical Journal, 55, 897.

EDITORIAL (1980). Management of severe hypercalcaemia. British Medical Journal, 280, 204.

FRAZER, D.R. (1980). Regulation of the metabolism of vitamin D. Physiological Reviews, 60 No. 2, 551.

MARONE, C., BERETTA-PICCOLI, C. \& WEIDMANN, P. (1981). Acute hypercalcaemic hypertension in man: rate of haemodynamics, catecholamines and renin. Kidney International, 20, 92.

QUEENER. S.F. \& BELL. N.H. (1976). Treatment of ex-

\section{Acknowledgements}

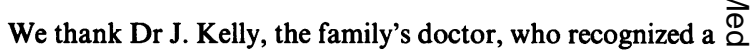
problem and arranged admission to hospital for it to be $C$ solved; and Dr R.W. Strachan for permission to describe the $\vec{F}$ parents who were his patients. We acknowledge the help and $\stackrel{\text { ? }}{+}$ advice of Dr A.V. Murphy and Dr J.B.P. Stephenson, of the Sick Children's Hospital, Glasgow; Dr I.T. Boyle and Dr F.J. Dryburgh of Glasgow Royal Infirmary; and Dr M.G. Dunnigan of Stobhill Hospital, Glasgow; on the investigation and treatment of this family. Also we thank Dr R.H. Cowan of Glasgow Royal Infirmary for measuring the serum $\infty$ levels of vitamin D metabolites, calcitonin and parathor- $\overrightarrow{0}$ mone; Dr B.F. Allam of Stobhill Hospital, Glasgow, for measuring the serum 25-hydroxyvitamin D levels; Dr C. Isles $\vec{\omega}$ of the M.R.C. Blood Pressure Unit, Western Infirmary, Glasgow, for arranging the serum aldosterone measurements; and Dr Cooke at the Laboratory of the 3 . Government Chemist in London, for analysing the specimen of oil. Finally we thank Dr Ross Wear of Dumfries \& ? Galloway Royal Infirmary for his report on the examination of the boys' eyes.

perimental vitamin D3 intoxication in the rat with cholestyramine. Clinical Research, 24, 503 A.

ROSENBERG, I.H., SITRIN, M.D. \& BOLT, M.J.G. (1979). The enterohepatic circulation of vitamin D: potential clinic implications. Vitamin D, Basic Research and its Clinic Application, Vol. 1, p. 487. Walter de Gruyer: Berlin, Ne York.

RUSSELL, R.G.C. (1975). Diphosphonates and polyphosphonates in medicine. British Journal of Hospital Medicine, 15, 297.

SANGAL, A.K. \& BEEVERS, D.G. (1983). Parathyroid hypertension. British Medical Journal, 286, 498.

UTTLEY, W.S., BELTON, N.R., SYME, J. \& SHEPPARD, H. (1975). Calcium balance in children treated with diphosphonates. Archives of Diseases in Childhood, 50, 187. 